\title{
Agricultural Sector FDI and Economic Growth in Saarc Countries
}

\author{
M. Arul Kumar, S. Gopalsamy
}

\begin{abstract}
The study seeks to establish the relationship between foreign direct investment to Saarc region agricultural sector and economic growth with secondary data. SAARC comprises $3 \%$ of the world's area, $21 \%$ of the world's population and $3.8 \%$ (US\$2.9 trillion) making up a total of $3 \%$ of the world's area. The country has second in all over the world in terms of agriculture position. The population obliquely all of the member states is over 1.7 billion, accounting for $21 \%$ of the world's total population. In their $42 \%$ of the agricultural operation in SAARC nations and also $51 \%$ source of livelihood of the South Asians. The study has revealed that India alone accounts for 52 per cent of the agricultural products using the SAARC region peoples. For the present study, a total of 34 groups related to the agricultural products were selected out of the total groups. The techniques employed to analyze the data include descriptive statistic, correlation and linear forecast method. The study also revealed a positive and important relationship between economic growth and foreign direct investment flow to the agricultural sector. Thus, the study recommends that policy should focus on flexible trade policies to attract more foreign direct investment (FDI) inflows to SAARC nations. i.e. Afghanistan, Bangladesh, Bhutan, Maldives, Nepal, Pakistan, Sri Lanka including India.
\end{abstract}

Keywords : Agricultural Sector, FDI, Economic Growth and SAARC countries.

\section{INTRODUCTION}

This paper reviews the agricultural sector in member countries of South Asian Association for regional cooperation (SAARC) and pays specific attention to issues of determining the potential FDI in the sector.FDI has been linked with improved economic growth and development in the host countries which has led to the materialization of global competition to attract FDI (Abhishek Vijaykumar Vyas, 2015). In the time of globalization, FDI takes a vital part in the development of both developing and developed countries. Foreign direct investment is one of the measures of growing economic globalization. Foreign investment plays a major role in the development of any economy as like India. Many countries provide much incentive for attracting foreign direct investment (FDI). In India, agriculture is an important sector of the Indian economy and accounts for almost $19 \%$ of Indian gross domestic products (GDP). Agriculture is the mainstay of the Indian economy as it

Revised Manuscript Received on September 25, 2019

M.Arul Kumar , PhD Scholar (Full-Time), Department of International Business, Alagappa University, Karaikudi - 630004

Dr.S.Gopalsamy, Assistant Professor, Department of International Business, Alagappa University, Karaikudi - 630004 forms the backbone of rural India which inhabitants more than $70 \%$ of total Indian population and supports their families which and thin(Anjali Chaudhary,2016). Investment has always been an issue for the developing economies such as India. Agriculture plays an important role in the economic development of any nation including India. Performance of Indian economy is dependent upon the growth of the agriculture sector. The sectoral distribution of FDI in the economy of SAARC may be similar to many other developing countries where FDI inflows to the agriculture sector are low and hence its contribution to agricultural growth and employment may be relatively less than manufacturing and agricultural sectors although it seems to have a positive effect on the economy in general.

\section{REVIEW OF LITERATURE}

Manamba Epaphra and Ales H. Mwakalasya (2017) this paper analyze the effect of foreign direct investment (FDI) on the agricultural sector in Tanzania. The paper also examines the declining contribution of agriculture to real GDP growth even though the sector employs more than 70 per cent of the total labour force. Annual time series data spanning from 1990 to 2015 are used to test the significance of the relationship between FDI inflow and agriculture value added-to-GDP ratio on one hand and FDI inflows and economic growth on the other hand. Also, the relationship between agriculture value-added and the economic growth rate is empirically examined. Variables such as gross fixed capital formation, inflation rate, trade liberalization, real exchange rate, and population are considered as control variables. For inference, the paper employs a classical linear regression model. Ordinary least squares methods are used for estimation. The diagnostic tests including RESET regression errors specification test, Breusch-Godfrey serial correlation LM test, Jacque-Bera-normality test and white heteroskedasticity test reveal that the models have no signs of misspecification and that, the residuals are serially uncorrelated, normally distributed and homoskedastic. Interestingly, empirical results suggest that there is no significant effect of FDI inflows on agriculture value added-to-GDP ratio in

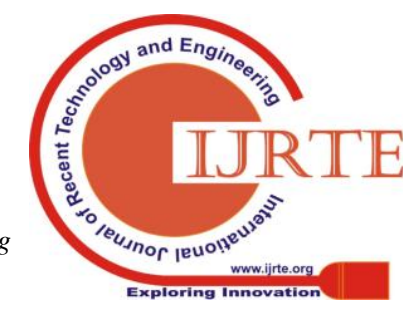


Tanzania despite the fact that FDI inflows in the economy have been outstanding particularly in the past two decades. Unsurprisingly, the results show that FDI inflows-to-GDP ratio and real GDP growth rate are positively correlated. Notwithstanding, the agriculture sector, which constitutes the largest proportion of the total labour force, contributes, on average, less than 30 per cent, to total GDP. This suggests that the sector is inefficient and therefore, an effort towards attracting more FDI aiming at improving productivity in the agriculture sector, which in turn may reduce poverty, is much needed.

Raka Saxena (2015) since regional associations and free trade are perceived to be welfare-enhancing, this paper has examined the structure and flow of trade among SAARC economies. The study has revealed that India alone accounts for 74 per cent of the agricultural exports from the region and 55 per cent of the agricultural imports of the region. Cotton, cereals, fish \& crustaceans, and tea \& beverages have emerged as the most exported commodities accounting for more than 50 per cent share of exports from SAARC countries to the world. Animal or vegetable fat, cotton and rubber are the most imported commodities by SAARC. India enjoys a comparative advantage in exports of cotton, cereals, fish and tea, while Pakistan has a greater comparative advantage in the export of cotton and cereals. A unidirectional causality has been observed between gross domestic product (GDP) and agricultural exports, where agricultural exports Granger cause GDP and notice Versa. A one-way causal relationship has also been observed between agricultural GDP and agricultural exports. This indicates that growth in agricultural exports has contributed to the overall and agricultural

growth in India. The study has suggested that the Indian trade policy environment needs to be made more favorable for attracting foreign buyers and making Indian exports competitive globally.

Kapil Singh and Ritu K. Walia (2015) Agriculture plays an important role in economic development of any nation including India. The contribution of agricultural sector to national Gross Domestic Product (GDP) has continued to decline over the years; while that of other sectors, particularly services, has increased. Presently, agriculture contributes 13.9 per cent of India's Gross Domestic Product (GDP) yet; agriculture forms the backbone of the economy, as 52 per cent of India's work force is still engaged in agriculture for its livelihood and is important for food security and inclusive growth. To improve agriculture productivity and streamline it with manufacturing and services sector, there is a strong need to adopt many measures, out of which, promote FDI inflow in the agriculture sector in the Indian economy. 100 per cent FDI is allowed in agriculture and allied service under controlled conditions. In the above regard, the present paper is an attempt to understand the role of FDI in the agricultural sector \& overall progress of the economy.

\section{OBJECTIVES OF THE STUDY}

The main objective of present study is

$\checkmark$ To study the conceptual framework for the agricultural sector FDI in SAARC countries.

$\checkmark$ To analyze the FDI and agricultural sector in Economic growth.

\section{RESEARCH METHODOLOGY AND DATA SOURCES}

The present study is of analytical and entirely based on secondary data which has been collected from the various issues of Handbook of Statistics on the Indian Economy and the study was conducted for a period of 5 years from 2015-2019.The available data has been processed and presented in the form of different suitable tables.

\section{HYPOTHESIS OF THE STUDY}

- There is no significant relationship between FDI Inflows and various SAARC Countries.

\section{RESULTS AND DISCUSSION}

Table -1 Descriptive Statistics on FDI Inflows in Afghanistan

FDI (Rs In Millions)

\begin{tabular}{|c|c|c|c|c|c|}
\hline Variable & $\begin{array}{c}\text { Maximum } \\
\text { Statistic }\end{array}$ & Mean & $\begin{array}{c}\text { Std. } \\
\text { Deviation }\end{array}$ & Skewness & Kurtosis \\
\hline FDI & 123 & 30.37 & 52.123 & 2.128 & 4.615 \\
\hline
\end{tabular}

Note: Normal Skew: 0; Mesokurtic: Kurtosis of 3.

FDI: Normal skewness and platykurtic (because 4.615>3) 
Table 2 Regression Analysis

\begin{tabular}{|c|c|c|c|}
\hline Variable & Co-efficient & t-statistic & prob \\
\hline C & 0.337 & 4.034 & 0.01 \\
\hline FDI & 30.37 & 0.621 & 0.000 \\
\hline R-Squared & .114 & Mean Dependent variable & 1.07 \\
\hline Adjusted R-Squared & -.182 & S.D Dependent Variable & 0.866 \\
\hline Sum Squared Residual & 3.212 & Durbin-Watson Stat & 1.517 \\
\hline F-Statistic & \multicolumn{3}{|c}{0.385} \\
\hline
\end{tabular}

Source: Researcher computed

The above is the linear regression analysis of Total foreign direct Investment (Dependent variable) and foreign direct investment (Independent variable) in table 2.1. From the analysis shows a significant relationship between Total FDI and FDI in SAARC Countries. Also the value of R2shows $11.4 \%$ determines the degrees of relationship between Total foreign Direct Investment and Foreign Direct Investment of Agricultural Sector in SAARC Countries.

Table 3 Descriptive Statistics on FDI Inflows in Bangladesh

FDI (Rs In Millions)

\begin{tabular}{|c|c|c|c|c|c|}
\hline Variable & $\begin{array}{c}\text { Maximum } \\
\text { Statistic }\end{array}$ & Mean & $\begin{array}{c}\text { Std. } \\
\text { Deviation }\end{array}$ & Skewness & Kurtosis \\
\hline FDI & 2 & .50 & .707 & .884 & -1.750 \\
\hline
\end{tabular}

Note: Normal Skew: 0; Mesokurtic: Kurtosis of 3.

FDI: normal skewness and platykurtic (because $-1.750<3$ )

Table 4 Regression Analysis

\begin{tabular}{|c|c|c|c|}
\hline Variable & Co-efficient & t-statistic & prob \\
\hline C & 0.204 & 3.711 & 0.01 \\
\hline FDI & 0.50 & 0.361 & 0.000 \\
\hline R-Squared & 0.042 & Mean Dependent variable & 1.158 \\
\hline Adjusted R-Squared & -.278 & S.D Dependent Variable & 0.866 \\
\hline Sum Squared Residual & 3.474 & Durbin-Watson stat & 1.372 \\
\hline F-Statistic & \multicolumn{3}{|c|}{0.131} \\
\hline
\end{tabular}

Source: Researcher computed

The above is the linear regression analysis of Total foreign direct Investment (Dependent variable) and foreign direct investment (Independent variable) in table 2.1. From the analysis shows a significant relationship between Total
FDI and FDI in SAARC Countries. Also the value of $\mathrm{R}^{2}$ shows $4.2 \%$ determines the degrees of relationship between Total foreign Direct Investment and Foreign Direct Investment of Agricultural Sector in SAARC Countries.

Table 5 Descriptive Statistics on FDI Inflows in Bhutan

\begin{tabular}{|c|c|c|c|c|c|}
\hline Variable & $\begin{array}{c}\text { Maximum } \\
\text { Statistic }\end{array}$ & Mean & $\begin{array}{c}\text { Std. } \\
\text { Deviation }\end{array}$ & Skewness & Kurtosis \\
\hline FDI & 32 & 12 & 16.016 & -.751 & 1.888 \\
\hline
\end{tabular}

Note: Normal Skew: 0; Mesokurtic: Kurtosis of 3.

FDI: normal skewness and platykurtic (because of $1.888<3$ )

Table 7 Regression Analysis

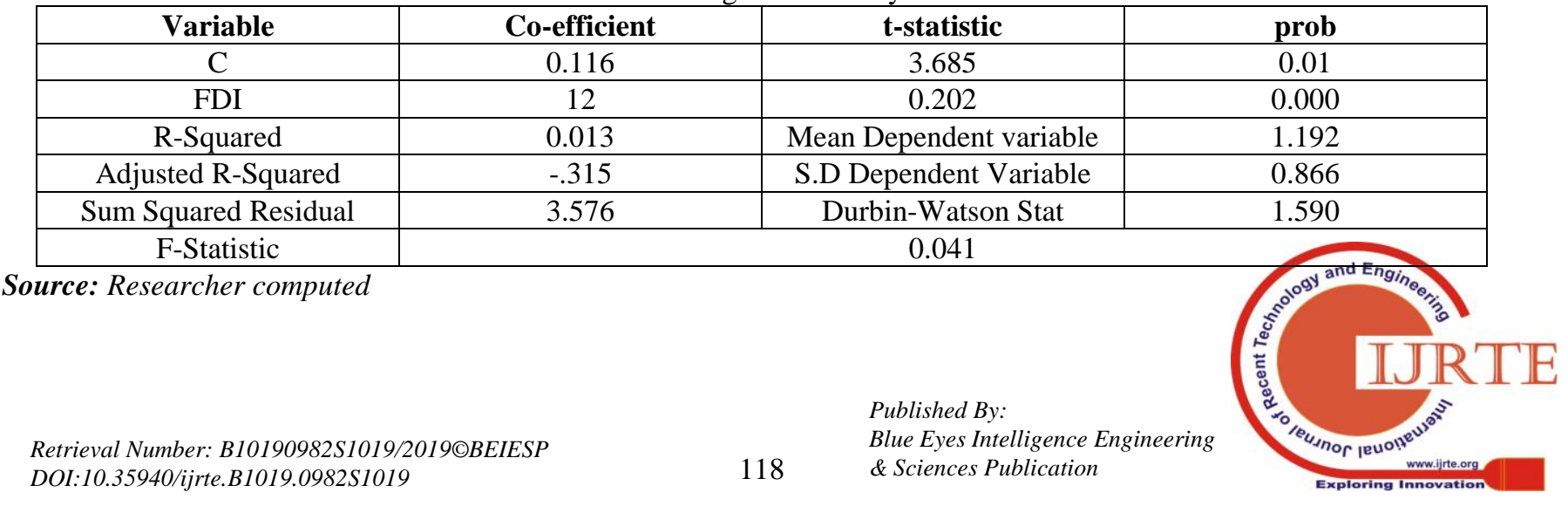


The above is the linear regression analysis of Total foreign direct Investment (Dependent variable) and foreign direct investment (Independent variable) in table 3.1. From the analysis shows a significant relationship between Total
FDI and FDI in SAARC Countries. Also the value of $\mathrm{R}^{2}$ shows $1.3 \%$ determines the degrees of relationship between Total foreign Direct Investment and Foreign Direct Investment of Agricultural Sector in SAARC Countries.

Table 8 Descriptive Statistics on FDI Inflows in Maldives

\begin{tabular}{|c|c|c|c|c|c|}
\hline Variable & $\begin{array}{c}\text { Maximum } \\
\text { Statistic }\end{array}$ & Mean & $\begin{array}{c}\text { Std. } \\
\text { Deviation }\end{array}$ & Skewness & Kurtosis \\
\hline FDI & 215 & 47.38 & 93.993 & 2.198 & 4.855 \\
\hline
\end{tabular}

Note: Normal Skew: 0; Mesokurtic: Kurtosis of 3.

FDI: normal skewness and platykurtic (because 4.855>3)

Table 9 Regression Analysis

\begin{tabular}{|c|c|c|c|}
\hline Variable & Co-efficient & t-statistic & prob \\
\hline C & 0.165 & 4.195 & 0.01 \\
\hline FDI & 47.38 & 0.202 & 0.000 \\
\hline R-Squared & 0.027 & Mean Dependent variable & 1.176 \\
\hline Adjusted R-Squared & -.297 & S.D Dependent Variable & 0.866 \\
\hline Sum Squared Residual & 3.527 & Durbin-Watson Stat & 1.631 \\
\hline F-Statistic & \multicolumn{3}{|c}{0.084} \\
\hline
\end{tabular}

Source: Researcher computed

The above is the linear regression analysis of Total foreign direct Investment (Dependent variable) and foreign direct investment (Independent variable) in table 4.1. From the analysis shows a significant relationship between Total
FDI and FDI in SAARC Countries. Also the value of $\mathrm{R}^{2}$ shows $2.7 \%$ determines the degrees of relationship between Total foreign Direct Investment and Foreign Direct Investment of Agricultural Sector in SAARC Countries.

Table 10 Descriptive Statistics on FDI Inflows in Nepal

\begin{tabular}{|c|c|c|c|c|c|}
\hline Variable & $\begin{array}{c}\text { Maximum } \\
\text { Statistic }\end{array}$ & Mean & $\begin{array}{c}\text { Std. } \\
\text { Deviation }\end{array}$ & Skewness & Kurtosis \\
\hline FDI & 14 & 7.56 & 6.147 & .092 & -2.151 \\
\hline
\end{tabular}

Note: Normal Skew: 0; Mesokurtic: Kurtosis of 3.

FDI: normal skewness and platykurtic (because $-2.151<3$ )

Table 11 Regression Analysis

\begin{tabular}{|c|c|c|c|}
\hline Variable & Co-efficient & t-statistic & prob \\
\hline C & .205 & 2.656 & 0.01 \\
\hline FDI & 7.56 & 0.363 & 0.000 \\
\hline R-Squared & 0.402 & Mean Dependent variable & 1.157 \\
\hline Adjusted R-Squared & -.277 & S.D Dependent Variable & 0.866 \\
\hline Sum Squared Residual & 3.472 & Durbin-Watson Stat & 1.477 \\
\hline F-Statistic & \multicolumn{3}{|c|}{0.132} \\
\hline
\end{tabular}

\section{Source: Researcher computed}

The above is the linear regression analysis of Total foreign direct Investment (Dependent variable) and foreign direct investment (Independent variable) in table 5.1. From the analysis shows a significant relationship between Total
FDI and FDI in SAARC Countries. Also the value of $\mathrm{R}^{2}$ shows $40.2 \%$ determines the degrees of relationship between Total foreign Direct Investment and Foreign Direct Investment of Agricultural Sector in SAARC Countries.

Table - 6 Descriptive Statistics on FDI Inflows in Pakistan

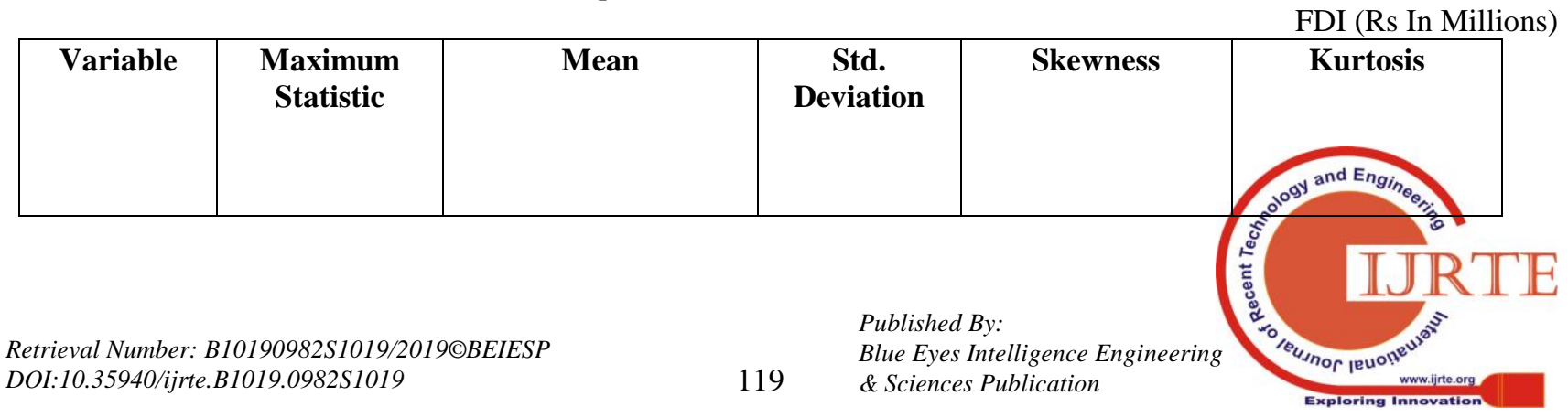




\begin{tabular}{|c|c|c|c|c|c|}
\hline FDI & 188 & 1393.44 & 445.811 & -.633 & -.414 \\
\hline
\end{tabular}

Note: Normal Skew: 0; Mesokurtic: Kurtosis of 3.

FDI: normal skewness and platykurtic (because $-.414<3$ )

Table 12 Regression Analysis

\begin{tabular}{|c|c|c|c|}
\hline Variable & Co-efficient & t-statistic & prob \\
\hline C & 0.058 & 2.254 & 0.01 \\
\hline FDI & 188 & 0.101 & 0.000 \\
\hline R-Squared & 0.003 & Mean Dependent variable & 1.204 \\
\hline Adjusted R-Squared & -.329 & S.D Dependent Variable & 0.866 \\
\hline Sum Squared Residual & 3.613 & Durbin-Watson Stat & 1.454 \\
\hline F-Statistic & \multicolumn{3}{|c}{0.010} \\
\hline
\end{tabular}

Source: Researcher computed

The above is the linear regression analysis of Total foreign direct Investment (Dependent variable) and foreign direct investment (Independent variable) in table 6.1. From the analysis shows a significant relationship between Total
FDI and FDI in SAARC Countries. Also the value of $\mathrm{R}^{2}$ shows $0.3 \%$ determines the degrees of relationship between Total foreign Direct Investment and Foreign Direct Investment of Agricultural Sector in SAARC Countries.

Table 13 Descriptive Statistics on FDI Inflows in Sri Lanka

\begin{tabular}{|c|c|c|c|c|c|}
\hline Variable & $\begin{array}{c}\text { Maximum } \\
\text { Statistic }\end{array}$ & Mean & $\begin{array}{c}\text { Std. } \\
\text { Deviation }\end{array}$ & Skewness & Kurtosis \\
\hline FDI & 1966 & 685.45 & 768.178 & 1.592 & 2.369 \\
\hline
\end{tabular}

Note: Normal Skew: 0; Mesokurtic: Kurtosis of 3.

FDI: normal skewness and platykurtic (because of $2.369<3$ )

Table 14 Regression Analysis

\begin{tabular}{|c|c|c|c|}
\hline Variable & Co-efficient & t-statistic & prob \\
\hline C & 0.451 & 3.277 & 0.01 \\
\hline FDI & 685.45 & 0.876 & 0.000 \\
\hline R-Squared & 0.204 & Mean Dependent variable & 9.621 \\
\hline Adjusted R-Squared & -.062 & S.D Dependent Variable & 0.866 \\
\hline Sum Squared Residual & 2.866 & Durbin-Watson stat & 1.894 \\
\hline F-Statistic & \multicolumn{3}{|c|}{0.768} \\
\hline
\end{tabular}

\section{Source: Researcher computed}

The above is the linear regression analysis of Total foreign direct Investment (Dependent variable) and foreign direct investment (Independent variable) in table 7.1. From the analysis shows a significant relationship between Total
FDI and FDI in SAARC Countries. Also, the value of $\mathrm{R}^{2}$ shows $20.4 \%$ determines the degrees of relationship between Total foreign Direct Investment and Foreign Direct Investment of Agricultural Sector in SAARC Countries.

Table 15 Correlation Analysis

\begin{tabular}{|c|c|c|c|}
\hline \multicolumn{2}{|c|}{} & $\begin{array}{c}\text { Foreign Direct } \\
\text { Investment }\end{array}$ & $\begin{array}{c}\text { Total Foreign Direct } \\
\text { Investment }\end{array}$ \\
\hline \multirow{2}{*}{$\begin{array}{c}\text { Foreign Direct } \\
\text { Investment }\end{array}$} & Pearson correlation & 1 & .495 \\
\cline { 2 - 4 } & Sig. (2-tailed) & 5 & .397 \\
\cline { 2 - 4 } & $\mathrm{N}$ & .495 & 5 \\
\hline \multirow{2}{*}{$\begin{array}{c}\text { Total Foreign Direct } \\
\text { Investment }\end{array}$} & Pearson correlation & .397 & 5 \\
\cline { 2 - 4 } & Sig.(2-tailed) & 5 & 5 \\
\cline { 2 - 4 } & $\mathrm{N}$ & 5 & 5 \\
\hline
\end{tabular}

**Correlation is significant at the level of 0.01

The Pearson correlation coefficient computed for FDI in SAARC Countries and Total FDI in Agricultural Sector is significantly higher. Hence, the Hypothesis is rejected. The results indicate the there is a significant positive relationship. 


\section{CONCLUSION}

From the researcher has been analyzed foreign direct investment of agricultural sector is now the preceding major boundary for globalized in SAARC Countries. Secondly, FDI inflows in India are always preferred by the developed countries. But the researcher made by the economic growth in 3.9 percentage in SAARC Countries. FDI inflows to South Asia increased by 3.5 percent investment in India. The largest recipient rose by six percent of SAARC Countries. SAARC has all the potentials and opportunity to grow faster like ASEAN and other than developed nations. Further prospects for FDI inflows into South Asia are largely determined by exceptions of economic growth in SAARC. Therefore it is high time for the Governments of those countries to take initiative to make SAARC a successful and developed economic region.

\section{REFERENCES}

1. Manamba Epaphra, Ales H. Mwakalasya. (2017). Analysis of Foreign Direct Investment, Agricultural Sector and Economic Growth in Tanzania. Modern Economy,(8),111-140.

2. Raka Saxena, Ranjit Kumar Paul, Simmi Rana, Shikha Chaurasia, Kavita Pal, Zeeshan and Deepika Joshi.(2015). Agricultural Trade Structure and Linkages in SAARC: An Empirical Investigation. Agricultural Economics Research Review, 28(2), 311-328.

3. Arul Kumar, M. Dr. Gopalsamy, S. (2018). FDI Regional Economic integration in SAARC Region. Roots International Journal of Multidisciplinary Researches,4(1).18-20.

4. Akinwale, Adekunle, E.Oludayo and Obagunwa. Busayo,T(2018).Foreign Direct Investment Inflow and Agricultural Sector Productivity In Nigeria. IOSR Journal of Economics and Finance, 9(4), 12-19.

5. Sonawane Shantaram Tarachand,(2017).A study on FDI in agriculture sector in India. International Journal of Multidisciplinary Education and Research, 2(3), 29-30.

6. Sharmin Akhter, (2019).Comparative Analysis of FDI in SAARC and ASEAN countries. IOSR Journal of Economics and Finance (IOSR-JEF), 10(2), 01-05.

7. Abhishek Vijaykumar Vyas,(2015),An Analytical Study of FDI in India (2000-2015). International Journal of Scientific and Research Publications, 5(10), 1-30.

8. Kapil Singh and Ritu Walia, K. (2015).Foreign Direct Investment (FDI) \& Agriculture Sector in India.PARIPEX - INDIAN JOURNAL OF RESEARCH, 4(1), 6-8.

9. Intan Maizura Abdul Rashid, Nor'aznin Abu Bakar, Nor Azam Abdul Razak,(2016). Determinants of Foreign Direct Investment (FDI) in Agriculture Sector based on Selected High-income Developing Economies in OIC Countries: An Empirical Study on the Provincial Panel Data by Using Stata, 2003-2012. Advances in Economics and Business, 4(9), 477-481. 